\title{
Techno-Environmental Assessment of Co-Gasification of Low-Grade Turkish Lignite with Biomass in a Trigeneration Power Plant
}

\author{
Ehsan Amirabedin ${ }^{1}$, Mirparham Pooyanfar ${ }^{2}$, Murad A. Rahim ${ }^{3}$, Hüseyin Topal ${ }^{4},{ }^{1-4}$ Gazi University
}

\begin{abstract}
Trigeneration or Combined Cooling, Heat and Power (CCHP) which is based upon combined heat and power (CHP) systems coupled to an absorption chiller can be recognized as one of the best technologies recovering biomass effectively to heat, cooling and power. Co-gasification of the lignite and biomass can provide the possibility for safe and effective disposal of different waste types as well as for sustainable and environmentally-friendly production of energy. In this article, a trigeneration system based on an IC engine and gasifier reactor has been simulated and realized using Thermoflex simulation software. Performance results suggest that utilization of sustainably-grown biomass in a Tri-Generation Power Plant (TGPP) can be a possibility for providing cooling, heat and power demands with local renewable sources and reducing the environmental impacts of the energy conversion systems.
\end{abstract}

Keywords - Trigeneration, biomass, co-gasification, emission, IC engine.

\section{INTRODUCTION}

In recent years, the growing need for energy recovery from renewable sources along with the necessity to mitigate environmental impact and supply costs has resulted in an increased interest in the thermal conversion of biomass/wastes. Biomass is one of the most promising resources which can serve as an alternative to fossil fuelgenerated energy. Biomass offers an alternative remedy for reducing emissions, if it may be replaced by part or in full in place of the fossil fuels of energy conversion systems, and would probably be the cheapest and lowest risk alternative for energy generation [1,2]. Biomass absorbs carbon dioxide from the atmosphere during growth and then releases it during combustion; therefore, biomass cannot be considered as a disturbance that could affect the balance of carbon dioxide and does not contribute to the net greenhouse effect [3, 4].

Trigeneration (i.e. CCHP) which is based upon combined heat and power (CHP) systems coupled to an absorption chiller can be recognized as one of the best technologies to recover biomass effectively to heat, cooling and power. Several previous studies in literature show that the trigeneration system is able to generate three useful energy forms with only a single fuel source [5-13]. However, trigeneration systems have been utilized for decades only in a small number of food manufacturing and retail facilities with limited fuel sources [14]. Nevertheless, there are some newer studies on different types of renewable fuel such as; jatropha oil [13], wood [15], biogas from sewage [16], willow, rice husk and miscanthus [17] showing that they are all highly potential fuels for trigeneration systems.

By taking these facts into consideration, if a trigeneration system based on a fluidized bed gasifier and IC engine is cofired with biomass, it would allow the utility production at lower fossil fuel consumption, less air and water pollutant production and would reduce overall facility expenditure [18].

The primary objective of this study is to investigate the feasibility of utilizing of biomass in a trigeneration system. The sub-objectives include:

- To design and simulate a trigeneration system based on a gasifier, an internal combustion engine, a steam turbine and a single-effect absorption chiller;

- To examine the performance of the system firing with different fuels like Tunçbilek lignite as the fossil fuel and olive pits, rice husk and pistachio shells as the renewable fuel;

- To investigate the variation of fuel consumption rate, energy efficiency, $\mathrm{CO}_{2}$ and $\mathrm{SO}_{2}$ emissions of system with respect to the different blends of Tunçbilek lignite and biomass types.

In this regard, first a trigeneration system firing with Tunçbilek coal has been simulated in THERMOFLEX simulation software [19], and then it is modified for co-firing with lignite and biomass.

\section{TURKEY’S BIOMASS ENERGY POTENTIAL}

Biomass can be considered as one of the most interesting renewable energy sources of Turkey, since its share of the total energy consumption of the country is approximately $10 \%$ (for year 2010), as shown in Table 1. In addition, the required technologies for converting biomass to useful energy are not necessarily complicated.

However, as a matter of fact, the implementation of biomass-based energy programs cannot be a definitive solution to the country's energy problems, but it could bring new insight for efficient energy use in the country, for instance, in the household sector, particularly in rural areas where $40 \%$ of the population lives (26 million). The estimates are based on the recoverable energy potential from the main agricultural residues, livestock farming waste, forestry and wood processing residues, as well as municipal waste [20]. 
TABLE I

TURKEY'S PRIMARY ENERGY CONSUMPTION IN GOE (BETWEEN 1990 AND 2010)

\begin{tabular}{|l|c|c|c|c|}
\hline Fuel source for each year (Goe) & $\mathbf{1 9 9 0}$ & $\mathbf{1 9 9 5}$ & $\mathbf{2 0 0 5}$ & $\mathbf{2 0 1 0}$ \\
\hline Coal & 6150 & 5905 & 12500 & 17000 \\
\hline Lignite & 9765 & 10570 & 30500 & 205000 \\
\hline Asphaltite & 123 & - & 23500 & 31000 \\
\hline Natural Gas & 3110 & 6218 & 39500 & 47000 \\
\hline Crude oil & 23901 & 29324 & 8500 & 11000 \\
\hline Hydropower & 1991 & 3057 & 180 & 350 \\
\hline Geothermal & 85 & 5512 & 2500 & 13000 \\
\hline Fuel wood & 5361 & 1556 & 125 & 3800 \\
\hline Waste & 2548 & 52 & 125310 & 250 \\
\hline Solar & 21 & 62332 & & 171650 \\
\hline Total consumption & 53055 & & & \\
\hline
\end{tabular}

Goe: Gigagrams of oil equivalent

Source: Ref. 21

It has been proved that the generation of electricity from biomass can be a promising method in the near future in Turkey. The electricity produced by direct combustion of biomass, advanced direct combustion, co-combustion with fossil fuels, gasification and pyrolysis technologies are almost ready for commercial-scale use. Turkey's first biomass power project is under development in Adana province, at an installed capacity of $45 \mathrm{MW}$. Two others, at a total capacity of $30 \mathrm{MW}$, are at the feasibility study stage in Mersin and Tarsus provinces [22].

\section{DESCRIPTION OF THE SYSTEM}

The schematic diagrams of the proposed energy system integrated with an $890 \mathrm{~kW}$ circulating fluidized bed gasifier and a $260 \mathrm{~kW}$ gas fired internal combustion engine, which is the basic primary mover of the system, are illustrated in Figure 1. The trigeneration system considered in this study consists of two main modules; CHP module and absorption chiller module.

The circulating fluidized bed biomass gasifier with an integrated gas cleaning system generates syngas as the main fuel of the IC engine. The engine cooling system is used to produce hot water at a temperature level adequate for domestic hot water or heating $\left(\sim 75^{\circ} \mathrm{C}\right)$. The combustion gas from the engine is directed to the absorption chiller for producing chilled water. The absorption system of the simulated facility is a single effect lithium bromide-water system (with capacity of approximately $100 \mathrm{~kW}$ ) which can deliver chilled water at $7^{\circ} \mathrm{C}$.

\section{FUEL CHARACTERISTICS}

Fuel properties and their composition have a great effect on the technical and environmental performance of energy conversion systems; therefore, the relevant details of the used lignite and biomasses including proximate analysis, ultimate analysis and calorific values have been given in Table 2 .
Tunçbilek lignite has a quite high calorific value of $23211 \mathrm{~kJ} / \mathrm{kg}$ (higher heating value, HHV). Other main characteristics of this lignite are; low content of the moisture $(7.50 \%)$ and sulphur $(1.81 \%)$ and higher content of fixed carbon $(41.3 \%)$.

On the other hand, higher levels of volatile matter and lower content of fix carbon are recorded for the all biomass types, which results in lower heating values compared to lignite.

\section{RESULTS AND DISCUSSION}

In this section, results of the simulation are presented, including technical and environmental performance of the system and assessments of the effects of varying fuel blends on the cycle performance.

For the technical performance of the system, the efficiency for both net electricity and trigeneration are calculated. For environmental performance, the amount of $\mathrm{SO}_{2}$ and $\mathrm{CO}_{2}$ emissions are used as indicators for monitoring the environmental impact of the system, considering the fact that sustainably-grown biomass is used as fuel or co-fuel.

The operating conditions taken for the simulation were; ambient temperature and pressure of $25^{\circ} \mathrm{C}$ and 1.013 bar, respectively, chilled water temperature and mass flow rate of $7^{\circ} \mathrm{C}$ and $10.44 \mathrm{t} / \mathrm{h}$, respectively, gasifier pressure and temperature of 1.2 bar and $850^{\circ} \mathrm{C}$, respectively, hot water temperature leaving the system of $75^{\circ} \mathrm{C}$ and for all fuel types, COP of the absorption chiller was selected as 0.55 .

\section{A. General technical and environmental results of TG system}

The proposed energy system operating with Tunçbilek lignite was successfully simulated using Thermoflex, then, in order to investigate the feasibility of using biomass as a fuel or secondary fuel in the trigeneration systems, the designed system was modified and co-fired with three types of biomass. 


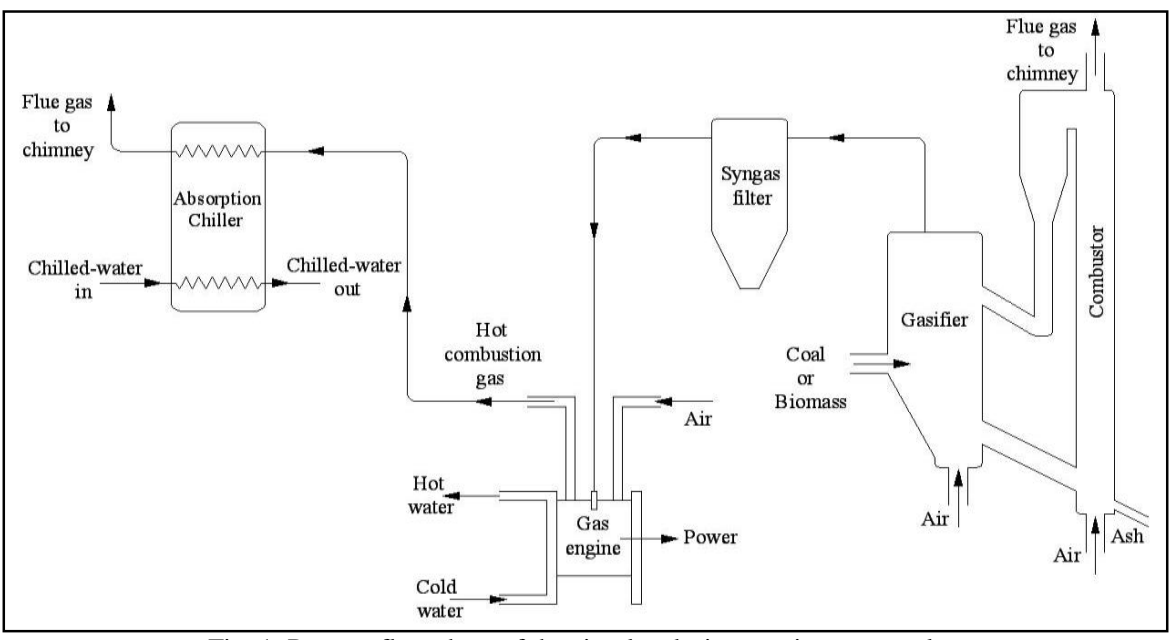

Fig. 1. Process flow sheet of the simulated trigeneration power plan.

TABLE II

THE CHARACTERISTICS OF OLIVE PITS, RICE HUSK, PISTACHIO SHELLS AND TUNÇBILEK LIGNITE (AS RECEIVED)

\begin{tabular}{|c|c|c|c|c|}
\hline & Olive pits & Rice husk & Pistachio shell & Tunçbilek coal \\
\hline \multicolumn{5}{|l|}{ Proximate analysis, $\%$} \\
\hline Moisture & 6.08 & 10.94 & 7.54 & 7.50 \\
\hline Volatile matter & 77.01 & 56.57 & 75.49 & 27.50 \\
\hline Ash & 1.62 & 18.05 & 1.3 & 23.70 \\
\hline Fix carbon & 15.29 & 14.44 & 15.67 & 41.30 \\
\hline \multicolumn{5}{|l|}{ Ultimate analysis, \% } \\
\hline Carbon & 49.57 & 34.58 & 46.42 & 55 \\
\hline Hydrogen & 6.28 & 4.23 & 5.84 & 4 \\
\hline Nitrogen & 0.42 & 0.46 & 0.64 & 2 \\
\hline Sulphur & 0.05 & 0.05 & 0.20 & 1.81 \\
\hline \multicolumn{5}{|l|}{ Thermal analysis, kJ/kg } \\
\hline Higher heating value (HHV) & 20277 & 14016 & 19698 & 23211 \\
\hline Lover heating value (LHV) & 18758 & 12916 & 18239 & 22041 \\
\hline
\end{tabular}

Some of the technical and environmental data of the system are presented in Table 3. As it can be seen from this table, system firing with Tunçbilek lignite has the highest process efficiency and the lowest fuel consumption rate with $80.83 \%$ and $136.8 \mathrm{~kg} / \mathrm{h}$, respectively among other fuel types. On the other hand, however, $\mathrm{SO}_{2}$ emission of the biomass is remarkably lower than lignite due to lower content of sulphur of the biomasses. The same cannot be saidin regard to $\mathrm{CO}_{2}$ emissions, since as it is presented in the table, the TG system for the lignite firing mode emits the lowest amount of $\mathrm{CO}_{2}$ at approximately $2.21 \mathrm{Mt} /$ year. The reason may be the lower amount of fuel consumption in comparison with other biomass types. However, it should be noted that biomass must not be considered as a disturbance which could contribute to the net greenhouse effect [4].

The synthesis gas mainly consists of $\mathrm{H}_{2}$ and $\mathrm{CO}$ and is commonly known as syngas. After the gasification process, the syngas passes through a cleaning system to remove undesirable pollutants such as tar and solid particles [23]. Table 4 summarizes the syngas composition produced after gasification for used lignite and biomass types.

When coal is used as the main fuel, the $\mathrm{CO}, \mathrm{H}_{2}$, and $\mathrm{CO}_{2}$ contents in the syngas are approximately $24.1 \%, 16.4 \%$, and $4.6 \%$, respectively, and a considerable quantity of $\mathrm{N}_{2}$, i.e. about $51.0 \%$, is produced. Meanwhile, when olive pit is used, the contents of $\mathrm{CO}, \mathrm{H}_{2}$, and $\mathrm{CO}_{2}$ in the product gas changed to $18.0 \%, 18.0 \%$, and $9.1 \%$, respectively. And when rice husk is supplied, the obtained syngas composition is similar to that of olive pits -- $\mathrm{H}_{2}$ and $\mathrm{CO}$ contents are somewhat low. For pistachio shell, the contents of $\mathrm{CO}, \mathrm{H}_{2}, \mathrm{CO}_{2}$ and $\mathrm{N}_{2}$ in the syngas are obtained as approximately $20.8 \%, 21.3 \%, 8.7 \%$ and $39 \%$, respectively. Moreover, lower heating values of the produced syngas from each fuel type are calculated as $3947 \mathrm{~kJ} / \mathrm{kg}, 3970 \mathrm{~kJ} / \mathrm{kg}, 4813 \mathrm{~kJ} / \mathrm{kg}$ and $4886 \mathrm{~kJ} / \mathrm{kg}$, respectively. In other words, syngas with an increased heating value is obtained with higher amounts of $\mathrm{CO}$ and lower amount of $\mathrm{CO}_{2}$. 
$2014 / 13$

TABLE III

TECHNICAL AND ENVIRONMENTAL DATA OF THE SIMULATED TRIGENERATION SYSTEM FOR DIFFERENT TYPES OF FUEL

\begin{tabular}{|c|c|c|}
\hline Parameter & Unit & Value \\
\hline \multicolumn{3}{|l|}{ Operating with olive pits } \\
\hline Net power & $\mathrm{kW}$ & 252.7 \\
\hline Net electric efficiency & $\%$ & 30.6 \\
\hline TG efficiency & $\%$ & 80.46 \\
\hline Fuel consumption rate & $\mathrm{kg} / \mathrm{h}$ & 162 \\
\hline Heat recovered from water-cooled condenser & $\mathrm{kW}$ & 314.5 \\
\hline $\mathrm{SO}_{2}$ emission & t/year & 1.31 \\
\hline $\mathrm{CO}_{2}$ emission & t/year & 2326.5 \\
\hline $\mathrm{CO}_{2}$ emission & $\mathrm{kg} / \mathrm{GJ}$ & 96618 \\
\hline \multicolumn{3}{|l|}{ Operating with rice husk } \\
\hline Net power & $\mathrm{kW}$ & 251.3 \\
\hline Net electric efficiency & $\%$ & 30.0 \\
\hline TG efficiency & $\%$ & 78.67 \\
\hline Fuel consumption rate & $\mathrm{kg} / \mathrm{h}$ & 237.6 \\
\hline Heat recovered from water-cooled condenser & $\mathrm{kW}$ & 311.5 \\
\hline $\mathrm{SO}_{2}$ emission & t/year & 1.93 \\
\hline $\mathrm{CO}_{2}$ emission & t/year & 2394.3 \\
\hline $\mathrm{CO}_{2}$ emission & $\mathrm{kg} / \mathrm{GJ}$ & 97864 \\
\hline \multicolumn{3}{|l|}{ Operating with pistachio shell } \\
\hline Net power & $\mathrm{kW}$ & 253.2 \\
\hline Net electric efficiency & $\%$ & 30.63 \\
\hline TG efficiency & $\%$ & 80.47 \\
\hline Fuel consumption rate & $\mathrm{kg} / \mathrm{h}$ & 165.6 \\
\hline Heat recovered from water-cooled condenser & $\mathrm{kW}$ & 314.7 \\
\hline $\mathrm{SO}_{2}$ emission & t/year & 5.37 \\
\hline $\mathrm{CO}_{2}$ emission & t/year & 2240.1 \\
\hline $\mathrm{CO}_{2}$ emission & $\mathrm{kg} / \mathrm{GJ}$ & 92952 \\
\hline \multicolumn{3}{|l|}{ Operating with Tunçbilek lignite } \\
\hline Net power & $\mathrm{kW}$ & 253.2 \\
\hline Net electric efficiency & $\%$ & 30.51 \\
\hline TG efficiency & $\%$ & 80.83 \\
\hline Fuel consumption rate & $\mathrm{kg} / \mathrm{h}$ & 136.8 \\
\hline Heat recovered from water-cooled condenser & $\mathrm{kW}$ & 320.4 \\
\hline $\mathrm{SO}_{2}$ emission & t/year & 40.46 \\
\hline $\mathrm{CO}_{2}$ emission & t/year & 2209.4 \\
\hline
\end{tabular}

TABLE IV

SYNGAS COMPOSITION (VOLUME PERCENT \%) FOR DIFFERENT FUEL TYPES

\begin{tabular}{|l|c|c|c|c|}
\hline Component & Olive pits & Rice husk & Pistachio shell & Tunçbilek coal \\
\hline $\mathbf{C O}$ & 17.92 & 16.6 & 20.74 & 24.07 \\
\hline $\mathbf{H}_{\mathbf{2}}$ & 17.94 & 19.08 & 21.27 & 16.35 \\
\hline $\mathbf{C O}_{\mathbf{2}}$ & 9.085 & 11.08 & 8.722 & 4.612 \\
\hline $\mathbf{C H}_{\mathbf{4}}$ & 0.0031 & 0.0024 & 0.006 & 0.009 \\
\hline $\mathbf{H}_{\mathbf{2}}$ & 0.0101 & 0.0149 & 0.047 & 0.3447 \\
\hline $\mathbf{H}_{\mathbf{2}} \mathbf{O}$ & 9.874 & 13.83 & 9.713 & 3.401 \\
\hline $\mathbf{C O S}$ & 0.0003 & 0.0004 & 0.0015 & 0.0162 \\
\hline $\mathbf{N}_{\mathbf{2}}$ & 44.63 & 38.92 & 39.03 & 50.6 \\
\hline $\mathbf{A r}$ & 0.5363 & 0.4668 & 0.4679 & 0.6039 \\
\hline $\mathbf{L H V}, \mathbf{k J} / \mathbf{k g}$ & $\mathbf{3 . 9 4 7}$ & $\mathbf{3 . 9 7 0}$ & $\mathbf{4 . 8 1 3}$ & $\mathbf{4 . 8 8 6}$ \\
\hline
\end{tabular}




\section{B. Effect of varying fuel blends on system performance}

In this section, the simulation results obtained through the variation of some essential parameters of the trigeneration system for different blends of Tunçbilek coal and biomasses are presented.

The motivation for utilizing trigeneration technology and biomass is not only financial. Other parameters, such as system efficiency and reduction in emissions should also be taken into account [23]. In this regard, besides the amount of fuel saved, the variation of the system efficiency and $\mathrm{CO}_{2}$ emission are investigated.

Figure 2 shows the fuel consumption rate against fuel types at different fuel blends. For all biomass types, the fuel consumption rate increases notably when the coal share in fuel blends reduces from $100 \%$ to $0 \%$. However, in all four cases, the fuel consumption of the rice husk is the highest. This is because of the lower calorific value of the rice husk in comparison with other biomass types.

Figure 3 illustrates the variation of energy efficiency of the TG system with different blends of Tunçbilek coal and biomass types. It can be observed that an increase of the biomass share in the fuel blends from $0 \%$ to $100 \%$ results in a slight decrease of the energy efficiency of the system for olive pits and pistachio shells. For both fuel types, energy efficiency decreases from $80.83 \%$ to $80.46 \%$. The same cannot be seen for rice husk, where an increase of rice husk share in the fuel blend results in a considerable reduction of efficiency from 80.83 to 78.67 .

The effect of the different blends of lignite and biomass types on $\mathrm{CO}_{2}$ emission of the trigeneration system is illustrated in Figure 4. As it can be seen from this figure, the increase of biomass share in fuel blends has different effects on $\mathrm{CO}_{2}$ emissions of lignite-biomass blends. The increase of the biomass share in fuel blends from $0 \%$ to $100 \%$ causes an approximate $117 \mathrm{t} /$ year increase of $\mathrm{CO}_{2}$ emissions for the system co-firing with olive pits and approximately $185 \mathrm{t} / \mathrm{year}$ increase for the system co-firing with rice husk. For the system co-firing with pistachio shell, $\mathrm{CO}_{2}$ emissions increase very slightly and remain nearly constant.

Figure 5 displays the variation of $\mathrm{SO}_{2}$ emissions of the TG system with different blends of Tunçbilek lignite and biomass. It is clear that for all investigated samples, $\mathrm{SO}_{2}$ emissions of the TG system reduces significantly when the lignite share in fuel blends decreases from $100 \%$ to $0 \%$.

\section{CONCLUSION}

The comprehensive simulation and thermodynamic analysis of a trigeneration system for electricity generation, heating and cooling has provided useful insight.

From the results and discussions, it can be concluded that:

- Trigeneration system firing with Tunçbilek lignite has the highest process efficiency and lowest fuel consumption rate in comparison to other fuels with $80.83 \%$ and $136.8 \mathrm{~kg} / \mathrm{h}$, respectively. In this mode, the system also emits the lowest amount of $\mathrm{CO}_{2}$ with approximately $2.21 \mathrm{Mt} / \mathrm{y}$. On the other hand, it also emits a much higher amount of $\mathrm{SO}_{2}$ at $40.46 \mathrm{t}$ /year.

- Lower heating values of the produced syngas from each fuel types are obtained as $3947 \mathrm{~kJ} / \mathrm{kg}, 3970 \mathrm{~kJ} / \mathrm{kg}, 4813 \mathrm{~kJ} / \mathrm{kg}$ and $4886 \mathrm{~kJ} / \mathrm{kg}$, respectively. It is shown that, syngas with higher amounts of $\mathrm{CO}$ and lower amount of $\mathrm{CO}_{2}$ has the higher heating value.

- Decrease of the coal share in the fuel blends from $100 \%$ to $0 \%$ results in a decrease of the fuel consumption rate of all biomass types. However, in all four fuel cases, the fuel consumption of the rice husk is the highest.

- For olive pits and pistachio shells, the decrease of the lignite share in the fuel blends results in a very slight decrease of the energy efficiency of the TG system, but for the rice husk it results in a considerable reduction.

- The increase of the biomass share in fuel blends has different effects on $\mathrm{CO}_{2}$ emissions.

- For all investigated samples, $\mathrm{SO}_{2}$ emissions of the $\mathrm{TG}$ system reduces numerously when the lignite share in fuel blends decreases.

\section{ACKNOWLEDGEMENTS}

The authors are grateful for being sponsored by Scientific Research Projects Unit (Project Code: 06/2010-20) of Gazi University.

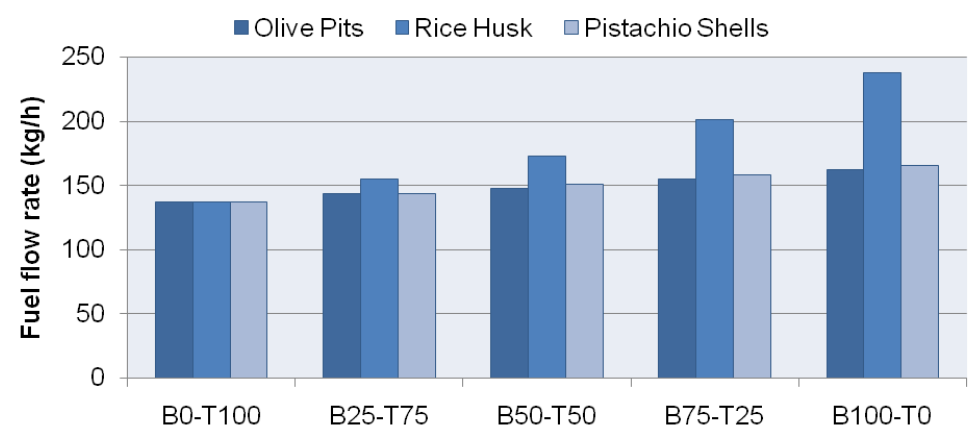

Fig. 2. Variation of fuel flow rate of the system with different blends of Tunçbilek coal and biomass types. 


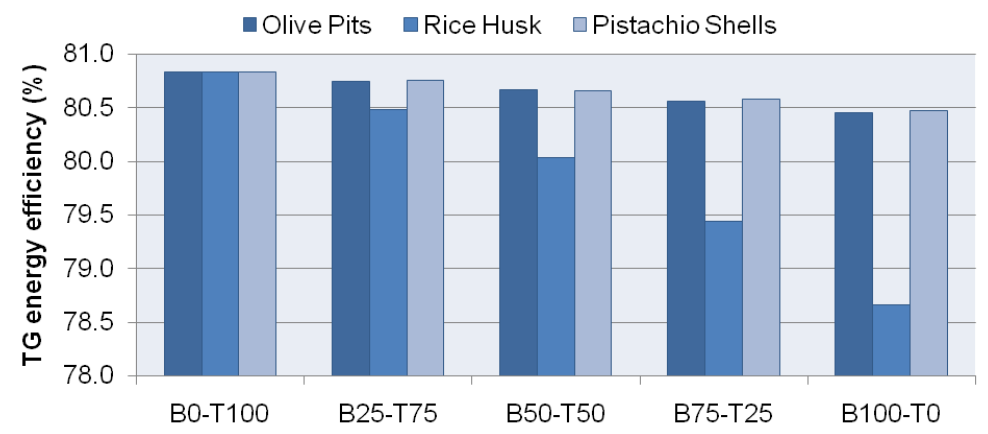

Fig. 3. Variation of the system energy efficiency with different blends of Tunçbilek coal and biomass types.

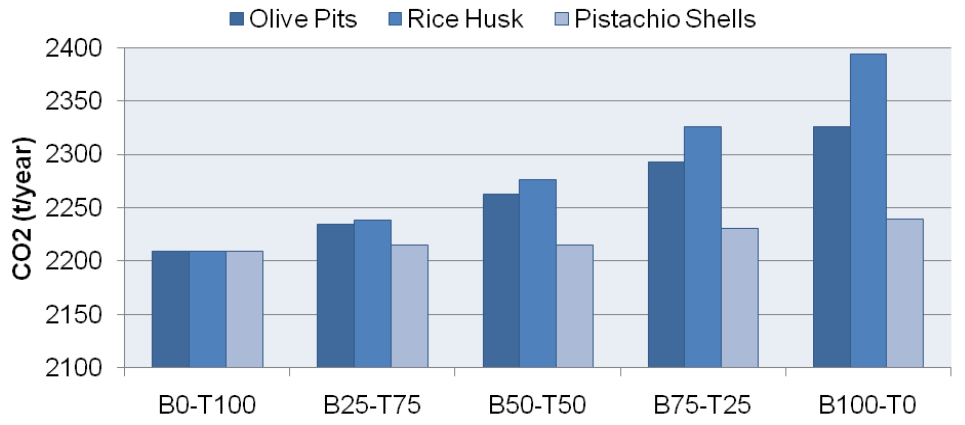

Fig. 4. Variation of the $\mathrm{CO}_{2}$ emission of the system with different blends of Tunçbilek coal and biomass types.

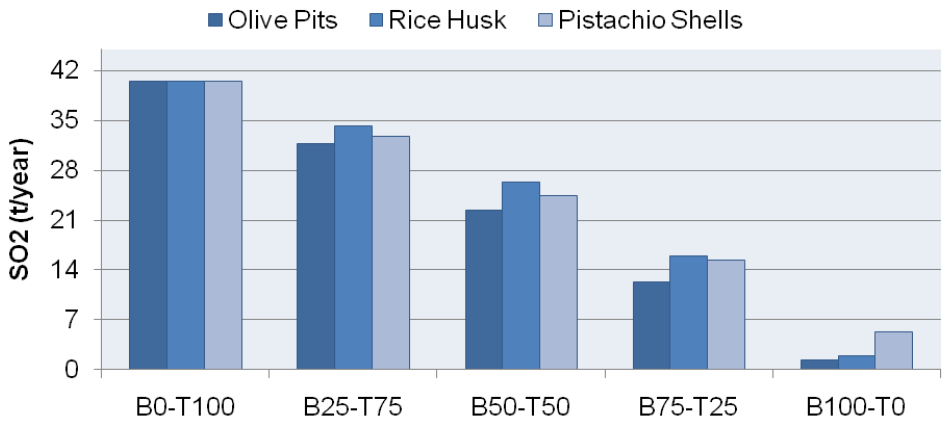

Fig. 5. Variation of the $\mathrm{SO}_{2}$ emission of the system with different blends of Tunçbilek coal and biomass types.

\section{REFERENCES}

1. Mcllveen-Wright, D. R., Huang, Y., Rezvani, S., Mondol, J. D., Redpath, D., Anderson, M., Hewitt, N. J., Williams, B. C. A technoeconomic assessment of the reduction of carbon dioxide emissions through the use of biomass co-combustion, Fuel, 2011, No. 90, pp. 24-32.

2. Baxter, L., Koppejan, J. Co-combustion of biomass and coal, Euroheat and Power (English Edition), 2004, No. 1, pp. 34-39.

3. Haykırı-Acma, H. Combustion characteristics of different biomass materials, Energy Conversion and Management, 2003, No. 44, pp. 155-162. http://dx.doi.org/10.1016/S0196-8904(01)00200-X

4. Yamamoto, K. Biomass power generation by CFB boiler, NKK Technical Review, 2001, No. 85.

5. Lin, L., Wang, Y., Al-Shemmeri, T., Zeng, S., Huang, J., He, Y., Huang, X., Li, S., Yang, J. Characteristics of a diffusion absorption refrigerator driven by the waste heat from engine exhaust", Proceedings of the Institution of Mechanical Engineers, Part E, Journal of Process Mechanical Engineering, 2006, No. 220, pp. 139-149.
6. Wang, Y. D., et. al. An experimental investigation of a household size trigeneration, Journal of Applied Thermal Engineering, (2007). 27, pp. 576-585. http://dx.doi.org/10.1016/j.applthermaleng.2006.05.031

7. Lin, L., Wang, Y., Al-Shemmeri, T., Ruxton, T., Turner, S., Zeng, S., Huang, J., He, Y., Huang, X. Energy efficiency and economic feasibility of CCHP driven by sterling engine, Energy Conversion and Management, 2004, No. 45, pp. 1433-1442.

8. Temir, G., Bilge, D. Thermoeconomic analysis of a trigeneration system, Applied Thermal Engineering, 2004, No. 24, pp. 2689-2699. http://dx.doi.org/10.1016/j.applthermaleng.2004.03.014

9. Calva, E. T., Núñez, M. P., Toral, M. A. R. Thermal integration of trigeneration systems, Applied Thermal Engineering, 2005, No. 25, pp. 973-984. http://dx.doi.org/10.1016/j.applthermaleng.2004.06.022

10. Rong, A., Lahdelma, R. An efficient linear programming model and optimization algorithm for trigeneration, Applied Energy, 2005, No. 82, pp. 40-63. http://dx.doi.org/10.1016/j.apenergy.2004.07.013

11. Ziher, D., Poredos, A. Economics of a trigeneration system in a hospital, Applied Thermal Engineering, 2006, No. 26, pp.680-687. http://dx.doi.org/10.1016/j.applthermaleng.2005.09.007 
12. Temir, G., Bilge, D., Emanet, G. An application of trigeneration and its economic analysis, Energy Sources, 2004, No. 26, pp. 857-867. http://dx.doi.org/10.1080/00908310490465894

13. Yaodong, W., Ye, H., Anthony, P., Yulong, D., Neil, H. Trigeneration running with raw jatropha oil, Fuel Processing Technology, 2010, No. 91, pp. 348-353.

14. Suamir, I., Tassou, S. A. Performance evaluation of integrated trigeneration and $\mathrm{CO} 2$ refrigeration systems, Applied Thermal Engineering, 2012, No. 11, pp. 1-9.

15. Eicker, U. Biomass trigeneration with decentral cooling by distric heating networks, Proceedings of 2 nd Polygeneration conference, Tarragona, 2011.

16. Bruno, J. C., Ortega-López, V., Coronas, A. Integration of absorption cooling systems into micro gas turbine trigeneration systems using biogas: Case study of a sewage treatment plant, Applied Energy, 2009 No. 86, pp. 837-847. http://dx.doi.org/10.1016/j.apenergy.2008.08.007

17. Huang, Y., Wang, Y. D., Rezvani, S., Mcllveen-Wright, D. R. Anderson, M., Hewitt, N. J. Biomass fuelled trigeneration system in selected buildings, Energy Conversion and Management, 2011, No. 52, pp. 2448-2454. http://dx.doi.org/10.1016/j.enconman.2010.12.053

18. Lai, S. M., Hui, C. W. Feasibility and flexibility for a trigeneration system, Energy 2009, No. 34, pp. 1693-1704. http://dx.doi.org/10.1016/j.energy.2009.04.024

19. Thermoflow (2008) Thermoflex, "Version 18, Thermoflow Inc., 29 Hudson Road Sudbury. MA 01776, USA.

20. Kaygusuz, K., Turker, M. F. Biomass energy potential in Turkey, Renewable Energy, 2002, No. 26, pp. 661-678. http://dx.doi.org/10.1016/S0960-1481(01)00154-9

21. Balat, M. Use of biomass sources for energy in Turkey and a view to biomass potential, Biomass and Bioenergy, 2005, No. 29, pp. 32-41. http://dx.doi.org/10.1016/j.biombioe.2005.02.004

22. Demirbas, A. Importance of biomass energy sources for Turkey, Energy Policy, 2008, No. 36, pp. 834-842. http://dx.doi.org/10.1016/j.enpol.2007.11.005

23. Munasinghe, P. C., Khanal, S. K. Biomass-derived syngas fermentation into biofuels: Opportunities and challenges, Bioresource Technology, 2010, No. 101, pp. 5013-5022.

http://dx.doi.org/10.1016/j.biortech.2009.12.098

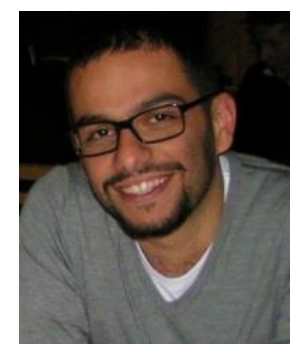

Ehsan Amirabedin was born in Tabriz, Iran, in 1982. He received a B. Sc. degree in mechanical engineering from the Azad University of Tabriz, in 2006, and a M. Sc. degree in mechanical engineering from the Gazi University, Ankara, Turkey in 2011. He is currently a PhD student in Gazi University. Six of his papers such as; Amirabedin E., Mcllveen-Wright D., A Feasibility Study of Co-Firing Biomass in the Thermal Power Plant at Soma in order to Reduce Emissions: an Exergy Approach, International Journal of Environmental Research, 2012, Amirabedin E., Durmaz A., Second law evaluation and sensitivity analysis of a Thermal Power Plant operating with 10 different types of low grade Turkish lignites, International Journal of Exergy, 2012, 3., have been published in international academic journals. His current research interests include energy conversion systems, renewable energy systems, combustion \& gasification technologies and energy \& exergy analysis of thermodynamic systems.

E-mail: ehsan.amirabedin@gmail.com

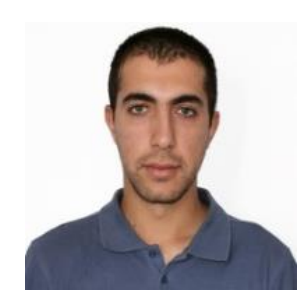

Mirparham Pooyanfar was born in 1986 and raised in Tabriz, Iran. He attended National Organization of Development of Exceptional Talents School as an honour student. Ranked among top $0.02 \%$ students in his country and decided to attend Amir Kabir University of Technology (AUT). Finished his B. Sc. at AUT in mechanical engineering. After gaining work experience working at Bandar-Abbas refinery and Bana Gostar Karaneh (BGK), two major corporations in Iran oil industry, started his M. Sc. at mechanical engineering department of Gazi University. His research interests are Sustainable Energies and CFD studies.

E-mail: p.pooyanfar@gmail.com

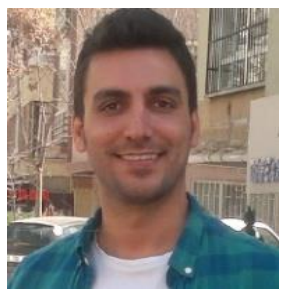

Murad A. Rahim was born in Kirkuk, Iraq, in 1981. He received a B. Sc. degree in Refrigeration and Air-Conditioning engineering from Kirkuk Technical Collage, in 2002, and a M. Sc. degree in mechanical engineering from the Gazi University, Ankara, Turkey, in 2008

$\mathrm{He}$ is currently a PhD student in Gazi University. Four of his papers have been published in international academic journals and he is awarded by TUBITAK. His current research interests include energy conversion systems, renewable energy systems, combustion \& gasification technologies and energy \& exergy analysis of thermodynamic systems.

E-mail: muradrahim@gmail.com

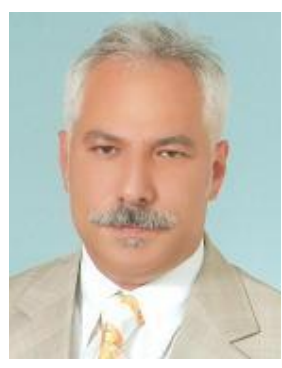

Hüseyin Topal completed his first degree studies at Gazi University Engineering and Architecture Faculty at the department of Mechanical Engineering in 1989. He took part in projects; "Investigation of the Causes of Air Pollution in Ankara and Measures for its Reduction" which are supported from NATO. In addition to these; he also completed his graduate studies within these projects. He made his $\mathrm{PhD}$ thesis according to the 'Circulating fluidized bed combusters'. Now he also works at Gazi Üniversity Engineering Faculty at the Department of Mechanical Engineering of Energy Fundamental as a staff member. Currently, he continues his studies at the beginning of biomass, the sources of renewable energies and the environmental effects. Below you can find some of his papers:

Topal H., Atimtay A. T., Durmaz A., Olive Cake Combustion in a Circulating Fluidized Bed, Fuel, Vol. 82, 1-8, 2003, Atimtay A. T., Topal H., Co-combustion of olivecake with lignite coal in a circulating fluidized bed, Fuel, Vol. 83, 7-8, pp. 859-867, 2004

Address: Gazi University, Faculty of Engineering, Department of Mechanical Engineering, $4^{\text {th }}$ Floor, Room 423, Eti District, Yukselis Street, No:5, PO Box 06570, Maltepe, Ankara, Turkey.

Phone: +90 5347394995

E-mail: htopal@gazi.edu.tr 